\title{
The Impacts of Variety on the Costs and profits of a Hotel Chain's Properties
}

\author{
Cathy A. Enz \\ Cornell University \\ Gordon Potter \\ Cornell University
}

\begin{abstract}
In the hotel industry, undistributed operating expenses represent a significant portion of the operating costs for a hotel. Exactly how most of these expenses arise is not well understood. Using data from more than 40 hotels operated by a major chain, the authors examine the links between the variety of a hotel's products and customers and its undistributed operating expenses and revenues. Their findings show that undistributed operating expenses are related to the extent of the property's business and product-services mix. The results suggest that although increasing a property's productservice mix results in higher undistributed operating expenses, the incremental costs are compensated for by higher revenues. However, increasing business mix while increasing undistributed operating expenses does not result in higher revenues.
\end{abstract}

Within the past 10 years traditional costing systems have been under critical reexamination (Kaplan, 1983, 1984). Cooper and Kaplan $(1987,1991)$ provide numerous examples of how a poor understanding of cost behavior can systematically distort the cost estimates of producing products and services and can provide little guidance to managers on how to identify areas for cost reduction. Understanding how costs behave is also critical for creating accurate budgets that are needed for planning and performance measurement (DeFranco, 1997; Schmid- gall \& Ninemeier, 1987). Unfortunately, we know little about how costs arise (Porter, 1985). In the hotel industry, undistributed operating expenses can represent a significant portion of the operating costs for a hotel. However, exactly how most of these expenses occur is not well understood. In part, this may be because there is no prescription for how these expenses should be controlled (see Hotel Association of New York City's [1986] $A$ Uniform System of Accounts). In this article we explore the linkage between undistributed operating expenses and the degree to which the customer mix at the hotel, as well by the different products (rooms, food, retail, etc.) offered at the hotel, varies. We also examine the relation between product and service variety and overall departmental income and profits. 
Following the ideas outlined in Skinner (1974), it has been argued by Cooper and Kaplan (1987) and Miller and Vollmann (1985) that product and service variety is a primary driver of costs. They state that as the offering of products and services expands, the complexity of the operations increases rapidly, leading to a sharp rise in support activities and, consequently, costs. An obvious management strategy given this belief is for firms to focus on a few products or services to control costs (Kekre and Srinivasan, 1990). However, from a marketing perspective, the desire to fulfill customer needs leads firms both to produce a variety of products and to provide numerous services for their customers. Firms are willing to expand their line of products and services because variety provides the customer with a better matching of his or her needs with products, which may result in the ability of the seller to raise prices (Chamberlin, 1962; Lancaster, 1990). More variety may also lead to higher market share (Bagozzi, 1986; Cravens and Woodruff, 1986). Because increasing market share has been documented to lead to higher profitability (Ravenscraft, 1983), providing a wide range of services or products may result in higher overall profitability despite the increasing costs.

In the lodging industry, hotels need to determine the types of customers they wish to attract (the business-mix issue). Lodging properties also need to establish the types of revenue sources they will make available to guests (the product- services-mix issue). Little guidance is provided regarding how expenses are affected by the variety of products and customers served by the hotel. The lodging industry is composed of a number of sectors, most principally fullservice and limited-service hotels. We examine the links between a property's business mix, and alternatively its product-service mix, and its financial results in full-service hotels. According to Host (Smith Travel Research, 1995), full-service hotels are those with rooms, restaurants, and meeting space as well as bell service and room service. They generally are midprice, upscale, or luxury hotels. In contrast, limited-service hotels are rooms-only operations with few other services and amenities. Typically, these hotels are in the budget- or economy-price segments. The analysis in this article is conducted by using data from a number of full- service hotels operated by one company. As such, the results may not be generalizable to limited-service properties.

\section{Background and Hypothesis}

\section{Impact of Variety on Undistributed Operating Expenses}

Economies of scope describe the impact on total costs attributable to the production of more than one product (Scherer \& Ross, 1990). Panzar and Willig (1977) and Willig (1979) demonstrate that positive economies of scope occur when there are cost complementarities between products. A cost complementarity is likely to be present when production and service processes share resources. For instance, if different products can use the same capital, then capacity can be used more effectively (Kekre \& Srinivasan, 1990). Products without these commonalities are likely to realize few benefits from scope economies. Moreover, as the number of customer groups or product lines increases, the complexity of the operations increases dramatically. This can lead to a sharp rise in support costs (Kekre \& Srinivasan, 1990). 
For instance, Skinner (1974) states that facilities that are focused on a narrow product mix are likely to have lower support costs than those producing many products because equipment, support systems, and procedures are all dedicated to a finite task. Product line expansion requires materials handling resources, more supervision, and may result in additional quality problems (Johnson \& Kaplan, 1987). A consequence of these factors is an upward pressure on costs (Scherer \& Ross, 1990).

The arguments above suggest that product variety leads to diseconomies of scope, which result in higher costs. Recently, cost driver analysis has been applied to manufacturing settings (Anderson, 1995; Banker, Potter, \& Schroeder, 1995; Foster \& Gupta, 1990) to obtain insights into the types of production processes and operating strategies that influence costs. Using number of products or product lines, Foster and Gupta (1990) and Banker et al. (1995) could not find evidence to support the hypothesis that product variety affects operating costeffectiveness. However, MacDuffie, Sethuranman, and Fisher (1996), using a measure of parts variety, and Anderson (1995), considering the similarities and differences among products, found that heterogeneity reduces manufacturing performance.

Little empirical work has been completed in the service area and none dealing with lodging properties. In a recent banking study, Banker, Ou, and Potter (1997) found a link between measures of product-line variety, service complexity, and costs. In a study of the airline industry, Banker and Johnston (1993) found that airline support costs increased with the complexity of operations as measured by the different types of aircraft and routes used by the carrier. It is well-known that Southwest's low-cost strategy includes highly standardized operations, no-frills flying, and a fleet that only contains $737 \mathrm{~s}$. Thus, reducing variety keeps complexity to a minimum and hence helps keep costs low.

In the hotel industry, undistributed operating expenses in a full-service hotel are incurred by providing services for guests and supporting revenue departments. We argue that as a property increases the number of customer groups and revenue sources it serves, operations become more complex. Therefore, more support personnel are needed to coordinate activities and correct errors. The result is a disproportionate increase in costs. For instance, consider the varying demands of a property's business mix (see Hanks, Cross, \& Noland, 1992). Leisure travelers typically check in early, check out late, and use many of the hotel's facilities. Business travelers check out early but require accurate messaging and billings. Administrative support services must be available to satisfy both groups' needs. In addition, because the marketing channels for the two groups differ, the property is required to use multiple advertising outlets and different marketing personnel. Additional errors are likely to occur if the property has different billing rates, amenities, and rooms for customer groups.

With respect to the product-service mix, rooms, food and beverage, gift shop, spa, and other departments consume different resources or the same resources in varying proportions. Rooms requires administrative resources for staffing, payroll and training, security, maintenance, and grounds. Food and beverage, as well as gift shop and other retail activities, 
draw heavily on purchasing, maintenance, regulatory compliance, and disbursing services. The varying demands for resources and expertise result in additional management. ${ }^{1}$ Also marketing and purchasing channels vary, requiring specialized personnel. Therefore, it is expected that undistributed operating expenses increase as a property's business mix or product-service mix expands. We test the following hypothesis:

Hypothesis 1: After controlling for other property characteristics, the greater the property's business or product-service variety, the higher its undistributed operating expenses.

\section{Impact of Variety on Revenues}

Abernathy and Wayne (1974) argue that variety can lead to an adaptable workforce, as workers who have to deal with a variety of operations are constantly learning. Therefore, they argue that variety should ultimately result in reduced costs as there is more process innovation occurring. Although their argument suggests a cost rationale for serving a variety of customer types and offering multiple revenue sources, most arguments for variety concern the desire to increase revenue. Profitability has been found to be positively and significantly related to market share (Gale and Branch, 1982; Ravenscraft, 1983). Robinson and Fomell (1985) report a strong association between market share and product-line breadth. Kekre and Srinivasan (1990) and Ittner, Larcker, and Randall (1996) document a link between measures of variety and revenues for manufacturers. Product differentiation strategies based on location/accessibility, quality, service, price, and image can be used to build market share (Scherer \& Ross, 1990) and raise prices (Kekre \& Srinivasan, 1990). Broader product lines allow sellers to more closely fulfill customer needs, leading to higher prices (Chamberlin, 1962).

Hotel revenue should increase as more products and services are offered. The existence and variety of food and beverage operations, such as fine dining, poolside, and catering should help attract and retain guests. A better matching of services with a guest's needs should result in enhanced guest loyalty and a greater willingness to pay high prices. The increased supply of hotel rooms following a construction boom in the 1980s has forced hotels to become more competitive ("Why Hotel Rates," 1993). In this environment, improvements in profitability are tied to the ability to increase revenues through price increases without losing customers (PKF Consulting, 1994). Instead of lowering prices, hotels attract business through improved perks such as airline discounts, free long-distance calls, frequent-traveler programs, and increased service ("Hotels Embrace," 1993). It is therefore expected that revenues will expand with increases in a hotel's business and product-service mix. We test the following hypothesis:

Hypothesis 2: After controlling for other property characteristics, the greater the customer or product variety, the higher the hotel's revenues. 


\section{Methodology}

\section{Data Source}

To investigate the impact of variety on costs and revenues, annual data were obtained for 1993 and 1994 for properties managed by a major chain. The chain owns, leases, manages, and franchises principally full-service hotels. The sample consists of more than 40 of the chain's managed hotels located in North Amercia. The individual hotels ranged in size from about 150 rooms to more than 2,000 rooms with an average of about 500 rooms. Detailed revenue, expense, and customer-mix data were collected from the financial ledgers maintained at the headquarters of the chain by the corporate accounting staff. In addition, nonfinancial information about the hotel property, area cost of living, and economic prospects were hand collected by the researchers for each property. Although the revenue and expense information is provided using the Hotel Association of New York City's (1986) A Uniform System of Accounts, employing observations from one chain helps ensure that the data are comparable. Using data from one chain also ensures that property-level differences are not due to different types of management styles or brand strategies.

\section{Dependent Variables}

The variables that measure financial performance are undistributed operating expenses, departmental income, and gross operating profit per available room. Gross operating profit is measured using the line "income before management fees and fixed charges" from A Uniform System of Accounts (Hotel Association of New York City, 1986). These measures are presented in Table 1. The primary focus of this article is on total undistributed operating expenses, denoted as TOTXPAR. To control for size differences across hotels, undistributed operating expenses are measured per available room. The undistributed expenses are further split into administrative and general (ADMXPAR), marketing (MRKXPAR), property, energy, maintenance, and other (OTHXPAR). This categorization is done because variety should have differing impacts on support resources. Revenue performance is measured using departmental income (NETREVPAR) per available room. Departmental income is computed as total hotel revenues minus departmental expenses. Departmental income can be considered the contribution of revenues to profits because it is computed after deducting the direct costs of providing the service or product. Subtracting all of the undistributed operating expenses from total revenues results in gross operating profit per available room (GOPPAR). This article does not have information on the value of assets in place, or fixed charges, that could be used to compute alternative measures of financial performance. Therefore, we are restricted to using gross operating profit as the measure of financial performance.

Table 1 shows the relation between the financial variables. The table also provides some information about the relative magnitudes of the revenue and expense components for the sample of hotels. The dependent variables of interest are identified in the table. ${ }^{2}$ The sample's various revenue and expense components as a proportion of sales are very similar to those of 
other full-service chain-affiliated hotels reported in The Hotel Operating Statistics (HOST) Report (Arthur Andersen, 1994; Smith Travel Research, 1995). The table reveals that for the

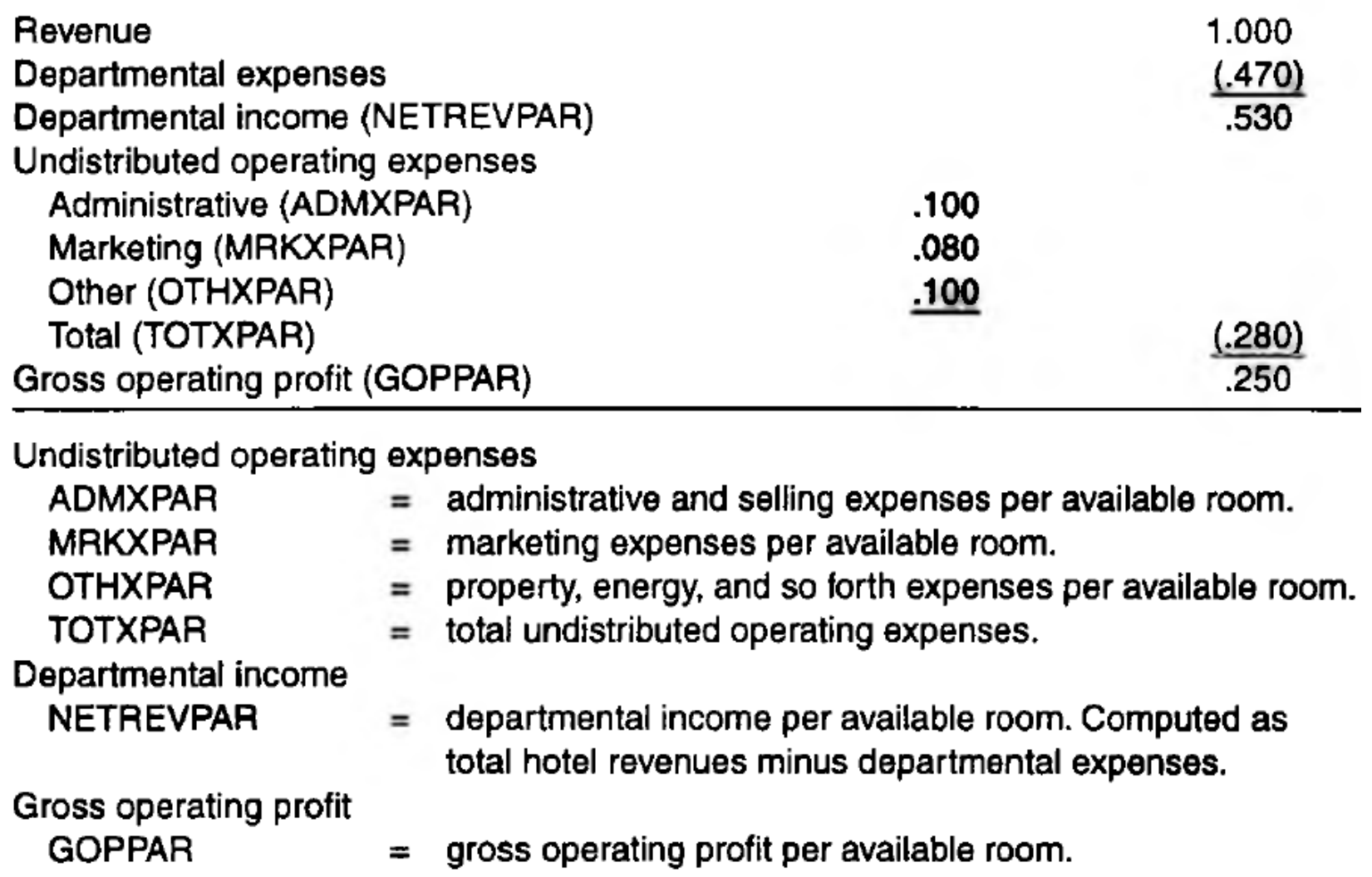

Table 1 Common-sized income statement (scaled by total revenue per available room)

sample department, expenses represent about $47 \%$ of total revenue, whereas HOST documents that full-service hotels with chain affiliation have departmental expenses as a ratio to sales of $43.4 \%$ in 1993 and $41.3 \%$ in 1994 . Undistributed operating expenses amount to about $28 \%$ of total revenue with administrative, marketing, and other expenses representing about equal portions in our sample. HOST reports undistributed operating expenses of $27.9 \%$ in 1993 , and $27 \%$ in 1994 . Clearly, undistributed operating expenses are a significant percentage of revenues. Gross operating profit, which is $25 \%$ of revenues, represents profits before management fees and fixed charges. Gross operating profit was reported as $28.8 \%$ in 1993 and $31.6 \%$ in 1994 for all chain-affiliated full-service hotels. Proportions of revenue and expenses reported in the exhibit for the hotel chain we studied are very similar to those of other fullservice hotels and are not similar to limited-service hotels, which according to the 1993 and 1994 HOST data (Arthur Andersen, 1993, 1994) show lower percentages for departmental expenses (29.0\% in 1993 and 27.5\% in 1994) and higher percentages for gross operating profit (43\% in 1993 and $45.2 \%$ in 1994). 


\section{Independent Variables}

An inverted Herfindahl Index is used to develop measures of variety. Measures of customer and product variety are based on a hotel's customer mix and, alternatively, product mix. The Herfindahl Index has been widely used as a measure of concentration in industrial economics (see, e.g., Scherer \& Ross, 1990; Stigler, 1983). The Herfindahl Index takes on a value between 1 and 0 , with 1 being total concentration. The inverted Herfindahl Index is a measure of variety; the higher the index, the greater the variety. Let $n$ be the number of product lines, the inverted Herfindahl Index is bounded between 1 and $n$, with 1 being total concentration and $n$ being total variety.

Assume that a hotel's customer mix includes corporate travelers (CTs), leisure travelers (LTs), and other associations and special groups (OTs). In this illustration, customer variety is measured as follows:

$$
\text { CUSTVAR }=1 / H I,
$$

where $\mathrm{HI}=$ Herfindahl Index of a hotel's customer mix,

$$
=\sum_{n=1}^{3} S_{a}^{2}
$$

$\mathrm{Sa}=$ the proportion of customers of Type $a$, where $a=\{C T, L T, O T\}$. By analogy, revenue mix (REVVAR) can be measured by rooms, food and beverage, and other revenue departments. In this study, there are four categories of CUSTVAR and three categories of REVVAR. The maximum value an inverted Herfindahl Index can take is equal to the number of customer or product-service classifications. The measure reaches its maximum when the proportions are equal.3

Economies of scale refer to the relationship between changes in outputs and changes in inputs due to the size of operations. Noreen and Soderstrom (1994) found positive economies of scale for the hospital industry, indicating that costs did not rise as fast as volume. Economies of scale may exist in the hotel industry due to the indivisibility of certain costs such as permits, safety inspections and other regulatory compliance activities, advertising, and management salaries, or the benefits that might accrue from purchase discounts for high-volume transactions and the benefits of labor specialization. Arnold (1994) states that undistributed operating expenses of lodging properties are mostly fixed in nature. We therefore include a variable for scale that is constructed as the inverse of number of hotel rooms (in hundreds), denoted SMALLSZ.

Occupancy rate will also determine the level of revenues and costs, as revenues and department expenses are directly related to occupancy and some administrative, marketing, and other costs such as energy and maintenance may move directly with rooms sold. We therefore control for differences in occupancy by including occupancy rate (OCCRATE) in the 
analysis. Indicator variables are also included for type of hotel, midpriced (MIDPRICE) or luxury (LUXURY) based on average daily rate (ADR) and classification, and for year. Because external factors, such as local market conditions measured by the area's unemployment rate (GROWTH) and the area's cost of living (COSTLIV), also affect a property's financial performance, these measures are also included in the analysis. The definitions of these variables are presented in Table 2.

Model of Expense Behavior

Empirical tests of the relations between variety and financial performance require the development of a model of the determinants of expenses and revenues. Although some

Panel A: Basic model

$$
\begin{aligned}
& \text { COST }_{\mathrm{it}}=\mathrm{FC}+\gamma_{0}{ }^{*} \text { Availroom }_{\mathrm{it}}+\gamma_{1}{ }^{*} \text { Occuproom }_{\mathrm{it}} \\
& \frac{\mathrm{COST}_{\mathrm{t}}}{\text { Availroom }_{*}}=\frac{\mathrm{FC}}{\text { Availroom }_{\mathrm{n}}}+\gamma_{0}+\gamma_{1} \text { Occrate }_{\mathrm{n}}, \\
& \text { UNDXPAR }_{\mathrm{it}}=\gamma_{0}+\gamma_{1} \text { OCCRATE }_{\mathrm{it}}+\gamma_{2} \text { SMALLSZ }_{\mathrm{it}}
\end{aligned}
$$

Panel B: Extended model

UNDXPAR $_{\mathrm{it}}=\gamma_{0}+\beta_{1}$ CUSTVAR $_{\mathrm{it}}+\beta_{2}$ REVVAR $_{\mathrm{it}}+\gamma_{1}$ OCCRATE $_{\mathrm{it}}+\gamma_{2}$ SMALLSZ $_{\mathrm{it}}+$ $\gamma_{3}$ MIDPRICE $_{i}+\gamma_{4}$ LUXURY $_{i}+\gamma_{5}$ GROWTH $_{i}+\gamma_{6}$ COSTLIV $_{i}+\gamma_{7}$ YEAR $_{i t}+e_{i t}$

$\begin{array}{ll}\text { Variety measures } & \\ \text { CUSTVAR } & =\text { measure of variety of customer types. } \\ \text { REVVAR } & =\text { measure of variety of sources of revenues. } \\ \text { Other measures } & \\ \text { OCCRATE } & =\text { annual occupancy rate. } \\ \text { SMALLSZ } & =\text { inverse of available rooms (in hundreds). } \\ \text { MIDPRICE } & =\text { indicator for a midpriced hotel. } \\ \text { LUXURY } & =\text { indicator for a luxury hotel. } \\ \text { GROWTH } & =\text { employment rate for county of property. } \\ \text { COSTLIV } & =\text { cost-of-living index for county of property. } \\ \text { YEAR } & =\text { indicator variable for year effect. }\end{array}$

Table 2 Model of Undistributed Operating Cost Behavior

expenses are fixed, most of a hotel's undistributed operating expenses are related to two key cost drivers. The first is the number of available rooms in a hotel. Property operation and maintenance costs, energy costs, property taxes, insurance costs, and some labor costs are examples of costs that are determined by the number of available rooms. These costs are usually considered to be support costs that are related to the hotel capacity measured by the number of available rooms (AR) for a cross section of hotels. In contrast, costs of room cleaning 
and food and beverages are driven by the number of occupied rooms. Although most of these latter costs are classified as departmental expenses, some of these, such as credit card commissions, data processing, loss damage, operating supplies, and some marketing activities, are included in undistributed operating expenses. This analysis suggests that total undistributed operating expenses for the hotel can be expressed as follows:

$$
\begin{gathered}
\text { Undistributed Operating Expenses }=\text { Fixed Cost }+ \\
\gamma_{0}^{*} \text { Number of Available Rooms }+\gamma_{1}^{*} \text { Number of Occupied Rooms. }
\end{gathered}
$$

In this format undistributed operating expenses include a purely fixed cost such as permit or filing fees, and then increases are based on both the number of rooms of a property and the number of rooms occupied. Dividing the above expression by the number of available rooms results in the model of undistributed operating expense behavior we use in the study. Panel $A$ of Table 2 depicts the undistributed operating expense per available room (UNDXPAR) for hotel $i$ in year $t$ as a function of a constant amount $\left(\gamma_{0}\right)$ that represents the fixed cost per available room, the occupancy rate for the hotel, and a charge $\gamma_{2}$, which represents an decrease in the cost per available room as a property gets larger. ${ }^{4}$ This occurs because larger hotels spread their pure fixed costs over a greater number of rooms.

Panel $B$ extends the basic model to include the measures for business mix and product service mix variety as well as other factors. The extended model indicates that expenses also increase with the amount of customer and product variety at the property (CUSTVAR or REVVAR). The other variables indicate that undistributed operating expenses per available room are related to the type of hotel (MIDPRICE or LUXURY), the local economy's growth (GROWTH), the local area's cost of living (COSTLIV), and the year. The coefficients for the variables indicate the impact of a 1-point change in an independent variable on costs. For instance, $\beta_{1}$, is the impact of a 1-point change in business mix variety on cost per available room. The extended model was estimated by using ordinary least squares regression.

\section{Research Results}

\section{Descriptive Statistics for Independent Variables}

Summary details on the independent variables used in this study are presented in Table 3. The data have been multiplied by a constant to help ensure confidentiality. Customer variety (CUSTVAR) and product variety (REVVAR) exhibit adequate variation with reasonably wide ranges given that there was a maximum of four customer groups and three revenue sources. There is also much variation in occupancy rate and hotel size as measured by OCCRATE and SMALLSZ, respectively. GROWTH, which is measured as one hundred minus the area's unemployment percentage, and the cost-of-living index suggest there are differences across properties. The correlations, presented in Panel B, suggest on average little significant correlation among the independent variables. However, customer variety is positively related to hotel size (the inverse of SMALLSZ) and positively related to growth. Revenue variety is negatively related to a property's occupancy rate. 


\begin{tabular}{lrrrr}
\hline $\begin{array}{l}\text { Panel A: Univariate Measures } \\
\text { Variable }\end{array}$ & $M$ & $S D$ & Minimum & Maximum \\
\hline CUSTVAR & 2.22 & 0.73 & 1.01 & 3.58 \\
REVVAR & 1.84 & 0.29 & 1.06 & 2.94 \\
OCCRATE & 70.95 & 9.33 & 44.30 & 87.63 \\
SMALLSZ & 2.54 & 1.55 & 0.41 & 6.66 \\
MIDPRICE & 0.44 & 0.49 & 0.00 & 1.00 \\
LUXURY & 0.06 & 0.23 & 0.00 & 1.00 \\
GROWTH & 92.94 & 2.18 & 88.00 & 96.50 \\
COSTLIV & 132.78 & 37.41 & 90.00 & 228.00
\end{tabular}

Panel B: Pearson Correlations

CUSTVAR REWVAR OCCRATE SMALLSZ MIDPRICE LUXURY GROWTH

\begin{tabular}{lrrrrrrr}
\hline CUSTVAR & 1.00 & & & & & & \\
REVVAR & .15 & 1.00 & & & & & \\
OCCRATE & -.17 & $-.35^{*}$ & 1.00 & & & & \\
SMALLSZ & $-.36^{*}$ & -.11 & -.16 & 1.00 & & & \\
MIDPRICE & .14 & -.01 & .19 & $-.26^{*}$ & 1.00 & & \\
LUXURY & -.18 & .02 & .13 & .10 & $-.22^{*}$ & 1.00 & \\
GROWTH & $-.24^{*}$ & .07 & .04 & .05 & -.12 & -.12 & 1.00 \\
COSTLIV & -.18 & .08 & $.30^{*}$ & .05 & $.20^{*}$ & $.24^{*}$ & .10 \\
\hline
\end{tabular}

Note: See Table 2 for definitions of variables.

" Significant at $5 \%$.

Table 3 Descriptive statistics for independent variables

Results Relating Variety to Undistributed Operating Expenses

Table 4 presents estimates of the impact of variety and the control measures on the undistributed operating expense components: administrative expenses (ADMXPAR), marketing expenses (MRKXPAR), and other expenses (OTHX-PAR). ${ }^{5}$ The adjusted $R^{2}$ s indicate that the variables explain between $76 \%$ and $62 \%$ of the variation in costs per available room. All three regression models are significant with $p$ values of .0001 . The upper left comer reports the impact of business mix variety (CUSTVAR) on administrative expenses per available room (ADMXPAR). The reported impact, .56, indicates that a 1-point increase in customer variety would increase administrative expenses by $\$ 0.56$ per available room. An examination of the customer mix impacts reveals that both administrative and marketing expenses increase as a property's business mix increases. There is little effect, either economically $(B=-.17)$ or statistically $(t=-.53)$, of business mix on other undistributed expenses. The results for revenue variety, REVVAR, indicate an economically large and statistically significant impact on costs (\$4.94 for administrative, $\$ 2.97$ for marketing, and $\$ 5.09$ for other). 
Table 4 also reveals the impact of occupancy rate, property size, class of property, and local economic factors on undistributed operating expenses. All three cost components increase with occupancy, but the impact is minimal and insignificant in two cases. The positive coefficient for SMALLSZ is large and significant, implying that hotel size clearly has an impact on cost per available room, with smaller properties having higher costs. Costs also increase with type of property and the local area's cost of living. Marketing costs decrease with growth of the local economy. Overall, the results indicate that, after controlling for a number of other variables thought to be related to undistributed operating expenses, variety is positively related to undistributed operating expenses.

UNDXPAR $_{t}=\gamma_{0}+\beta_{1}$ CUSTVAR $_{1 t}+\beta_{2}$ REVVAR $_{t t}+\gamma_{1}$ OCCRATE $_{n}+\gamma_{2}$ SMALLSZ $_{n}+$

\begin{tabular}{|c|c|c|c|c|}
\hline Predictor & Coefficient & ADMXPAR & MRKXPAR & OTHXPAR \\
\hline INTERCEPT & $\gamma_{0}$ & $\begin{array}{c}-0.65 \\
(-0.07)\end{array}$ & $\begin{array}{c}15.72 \\
(2.01)\end{array}$ & $\begin{array}{c}5.06 \\
(0.52)\end{array}$ \\
\hline CUSTVAR & $\beta$, & $\begin{array}{r}0.56^{*} \\
(1.86)\end{array}$ & $\begin{array}{r}1.02^{*} \\
(3.86)\end{array}$ & $\begin{array}{c}-0.17 \\
(-0.53)\end{array}$ \\
\hline REVVAR & $\beta_{2}$ & $\begin{array}{c}4.94^{*} \\
(6.92)\end{array}$ & $\begin{array}{c}2.97^{*} \\
(4.70)\end{array}$ & $\begin{array}{c}5.09^{*} \\
(6.50)\end{array}$ \\
\hline OCCRATE & $\gamma_{1}$ & $\begin{array}{c}0.03 \\
(1.29)\end{array}$ & $\begin{array}{c}0.04 \\
(1.63)\end{array}$ & $\begin{array}{c}0.05^{*} \\
(1.88)\end{array}$ \\
\hline SMALLSZ & $\gamma_{2}$ & $\begin{array}{r}1.43^{*} \\
(10.63)\end{array}$ & $\begin{array}{c}0.91^{*} \\
(7.63)\end{array}$ & $\begin{array}{c}0.56^{*} \\
(3.82)\end{array}$ \\
\hline MIDPRICE & $\gamma_{\mathbf{s}}$ & $\begin{array}{c}3.28^{*} \\
(7.89)\end{array}$ & $\begin{array}{c}2.39^{\circ} \\
(6.56)\end{array}$ & $\begin{array}{c}2.76^{*} \\
(6.06)\end{array}$ \\
\hline LUXURY & $\gamma_{4}$ & $\begin{array}{r}6.65^{*} \\
(7.27)\end{array}$ & $\begin{array}{r}5.60^{*} \\
(6.94)\end{array}$ & $\begin{array}{c}5.04^{*} \\
(5.02)\end{array}$ \\
\hline COSTLIV & $\gamma_{k}$ & $\begin{array}{r}0.03^{*} \\
(4.51)\end{array}$ & $\begin{array}{c}0.01 \\
(-0.81)\end{array}$ & $\begin{array}{c}0.03^{*} \\
(5.26)\end{array}$ \\
\hline GROWTH & $\gamma_{6}$ & $\begin{array}{c}-0.09 \\
(-1.05)\end{array}$ & $\begin{array}{c}-0.22^{*} \\
(-2.71)\end{array}$ & $\begin{array}{c}-0.15 \\
(-1.47)\end{array}$ \\
\hline YEAR & $\boldsymbol{r}_{\boldsymbol{r}}$ & $\begin{array}{c}-0.49 \\
(-1.33)\end{array}$ & $\begin{array}{c}0.07 \\
(-0.21)\end{array}$ & $\begin{array}{c}-0.07 \\
(-0.17)\end{array}$ \\
\hline $\begin{array}{l}\text { Adjusted } P^{2} \\
F \text { (model) } \\
P \text { (model) }\end{array}$ & & $\begin{array}{c}.76 \\
35.26 \\
.0001\end{array}$ & $\begin{array}{r}.62 \\
18.57 \\
.0001\end{array}$ & $\begin{array}{c}.67 \\
22.68 \\
.0001\end{array}$ \\
\hline
\end{tabular}

Note: See Tables 1 and 2 for definitions of variables.

"Significant at $5 \%$ (one-tailed test).

Table 4 Impact of Independent Variables on Undistributed Operating Costs ( $t$ statistics) 


\section{Results Relating Variety to Departmental Income and Gross Operating Profit}

The association between variety and revenues and profits is presented in Table 5. CUSTVAR has a negative, but insignificant at $5 \%$, impact on departmental income (NETREVPAR). This suggests that trying to serve a number of customer groups does not affect net revenue per room. Product variety, REVVAR, has a positive and significant effect on departmental income. This suggests that offering a variety of products and services has the effect of increasing departmental income by $\$ 18.07$. Other factors affecting net revenue per room are occupancy, hotel type as measured by MIDPRICE and LUXURY, and GROWTH.

\begin{tabular}{|c|c|c|c|c|}
\hline Predictor & Coefficient & NETREVPAR & TOTXPAR & GOPPAR \\
\hline INTERCEPT & $\gamma_{0}$ & $\begin{array}{r}-196.07 \\
(-3.47)\end{array}$ & $\begin{array}{c}21.99 \\
(1.16)\end{array}$ & $\begin{array}{r}-218.08 \\
(-4.06)\end{array}$ \\
\hline CUSTVAR & $\beta_{1}$ & $\begin{array}{l}-3.03 \\
(-1.56)\end{array}$ & $\begin{array}{c}1.40^{*} \\
(2.18)\end{array}$ & $\begin{array}{l}-4.43^{*} \\
(-2.43)\end{array}$ \\
\hline REVVAR & $\beta_{2}$ & $\begin{array}{c}18.07^{*} \\
(3.96)\end{array}$ & $\begin{array}{c}12.89^{*} \\
(8.43)\end{array}$ & $\begin{array}{c}5.17 \\
(1.19)\end{array}$ \\
\hline OCCRATE & $\gamma_{1}$ & $\begin{array}{c}1.19^{*} \\
(7.66)\end{array}$ & $\begin{array}{c}0.12^{*} \\
(2.20)\end{array}$ & $\begin{array}{c}1.08^{*} \\
(7.28)\end{array}$ \\
\hline SMALLSZ & $\boldsymbol{\gamma}_{\boldsymbol{z}}$ & $\begin{array}{c}-1.02 \\
(-1.19)\end{array}$ & $\begin{array}{l}2.88^{*} \\
(9.93)\end{array}$ & $\begin{array}{l}-3.90^{*} \\
(-4.75)\end{array}$ \\
\hline MIDPRICE & $\gamma_{\mathbf{a}}$ & $\begin{array}{c}26.83^{*} \\
(10.10)\end{array}$ & $\begin{array}{c}8.49^{*} \\
(9.53)\end{array}$ & $\begin{array}{c}18.33^{*} \\
(7.26)\end{array}$ \\
\hline LUXURY & $\gamma_{4}$ & $\begin{array}{c}57.12^{*} \\
(9.78)\end{array}$ & $\begin{array}{c}17.47^{\star} \\
(8.92)\end{array}$ & $\begin{array}{c}39.64^{\prime \prime} \\
(7.14)\end{array}$ \\
\hline COSTLIV & $\boldsymbol{\gamma}_{\boldsymbol{B}}$ & $\begin{array}{c}-0.01 \\
(-0.23)\end{array}$ & $\begin{array}{c}0.06^{*} \\
(4.47)\end{array}$ & $\begin{array}{l}-0.06^{*} \\
(-1.82)\end{array}$ \\
\hline GROWTH & $\gamma_{6}$ & $\begin{array}{r}1.46^{*} \\
(2.45)\end{array}$ & $\begin{array}{c}-0.48^{*} \\
(-2.44)\end{array}$ & $\begin{array}{r}1.94^{*} \\
(3.44)\end{array}$ \\
\hline YEAR & $\gamma_{7}$ & $\begin{array}{c}-1.00 \\
(-0.42)\end{array}$ & $\begin{array}{c}-0.42 \\
(-0.52)\end{array}$ & $\begin{array}{c}-0.58 \\
(-0.25)\end{array}$ \\
\hline Adjusted $R^{2}$ & & $\begin{array}{r}.78 \\
4006\end{array}$ & $\begin{array}{r}.79 \\
4396\end{array}$ & $\begin{array}{r}.73 \\
3089\end{array}$ \\
\hline $\begin{array}{l}F(\text { model }) \\
P \text { (model) }\end{array}$ & & $\begin{array}{l}40.06 \\
.0001\end{array}$ & $\begin{array}{l}43.96 \\
.0001\end{array}$ & $\begin{array}{r}30.89 \\
.0001\end{array}$ \\
\hline
\end{tabular}

Note: See Tables 1 and 2 for definitions of variables.

- Significant at 5\% (one-tailed test).

Table 5 Impact on Independent Variables on Financial Performance ( $t$ statistics) 
The impact of a variable on profits is reported in the column on the right. This coefficient can also be derived by subtracting the variable's TOTXPAR coefficient from its NETREVPAR coefficient. The coefficient estimates reveal that increasing the number of customer segments served has a significant negative effect on gross operating profit of $\$-4.43$. This occurs because, although variety is costly, customer variety does not increase revenues. Product/service variety, however, has a positive, but insignificant, impact on profitability. That is, even though costs increase by $\$ 12.89$ for each 1 -point increase in variety, these costs are compensated for by the increasing net revenue of $\$ 18.07$. Other variables affecting the bottom line include hotel size, occupancy rate, hotel type, cost of living, and growth.

\section{Discussion}

Overall, the results indicate that both customer and product/service variety are related to undistributed operating expenses. This suggests that properties serving a number of customer groups or providing a number of revenue sources should be aware how this "lack of focus" results in higher undistributed operating expenses. With respect to revenue mix, the link between variety and costs is perhaps not surprising as more revenue sources require additional support personnel for purchasing and billing, different marketing channels, and different types of property operations. However, we are unaware of any other work documenting the link between measures of customer or product variety and undistributed operating expenses.

Whereas it is easy to understand the positive impact of customer variety on undistributed operating expenses, it is difficult to explain why an increase in customer variety results in a drop in gross operating profit. One possible explanation has to do with management's choice to reduce room rates to attract new customer types, thus raising occupancy rates. In this study, occupancy rate is assumed to be exogenous; therefore, the impact of customer variety on occupancy, if any, is not accounted for. It may be that managers knowingly trade off the costs of customer mix for higher occupancy. Although this article does not address the relation between customer mix and occupancy, Table 5 reports that a 1-point increase in customer variety results in a $\$ 4.43$ drop in profits and that a 1-point increase in occupancy results in a $\$ 1.08$ increase in profits. Therefore, in this study, a property would need to realize a little more than a 4-point increase in occupancy (4.43 divided by 1.08 ) to compensate for a 1-point increase in customer mix. Of course, occupancy may not be related to customer mix (it is not in the pairwise correlations); rather, the results may be explained by some other factor such as the impact of lack of customer focus on customers' willingness to pay premium prices or the negative impact variety may have on the ability of the property to manage yield.

One limitation of the study is that the results are for a single major chain during a short time period. There is always the possibility that other factors are responsible for the documented relations, and therefore the results are not generalizable to other periods or 
companies. In addition, because profitability is measured using gross operating profit, there is the possibility that profit differences ascribed to variety can be explained by the level of investment required by different property types. Additional research is necessary to isolate additional causes of the documented relations.

\section{Conclusions}

Understanding how costs behave is critical for creating accurate budgets and controlling operations to improve profitability. In the hotel industry, undistributed operating expenses can represent a significant portion of the operating costs of a property. However, exactly how most of these expenses arise is not well understood. Moreover, there is little attempt to link the occurrence of these costs to revenue-sustaining activities. In this article we investigated the impact of the customer mix and the variety of products (rooms, food, retail, etc.) offered at the hotel on undistributed operating expenses and profitability.

The article documents that costs increase disproportionately with increases in variety. As such, the article adds to our understanding of the link between variety and a property's undistributed operating expenses. It suggests that properties need to be careful when assessing the cost impacts of an expansion of their product or customer base. We also find that the increasing costs associated with an expansion of product/service variety are compensated for with incremental revenue. The same cannot be said for an expansion of a property's customer mix.

\section{Notes}

1. Other ways to reduce complexity may be to lease out facilities to independent contractors and to outsource the provision of services and products.

2. The proportions reported should be interpreted cautiously as they have been altered slightly to ensure confidentiality.

3. An example of the inverted Herfindahl Index is presented below. Assume the following customer room nights:

$\begin{array}{ll}\text { Leisure } & 20,000 \\ \text { Corporate } & 25,000 \\ \text { Other } & 5.000 \\ \text { Total } & 50,000\end{array}$

Using these proportions, a Herfindahl Index (HI) is computed as

$$
H I=(20,000 / 50,000)^{2}+(25,000 / 50,000)^{2}+(5,000 / 50,000)^{2}=.42
$$

and customer variety is 


$$
\text { CUSTVAR }=1 / \mathrm{HI}=2.3809 \text {. }
$$

4. Note that as a hotel gets larger SMALLSZ goes down.

5. Because 2 years of data are used, some properties are in the sample twice. This suggests that some of the regression error terms may be correlated. To control for this, the impacts were estimated for each year separately. The yearly regression results were similar to those reported in the tables.

\section{Acknowledgements}

The authors acknowledge the contributions of David Corsum, James Scott, and Robert Wong during the data entry stage of this project. Funding for this project was provided by the Cornell University Center for Hospitality Research. An earlier version of this article was presented as a paper at the Cornell University Research Forum of the New York Hotel Show.

\section{References}

Abernathy, W. J., \& Wayne, K. (1974, September/October). Limits of the learning curve. Harvard Business Review, pp. 109-118.

Anderson, S. (1995, July). Measuring product mix flexibility: An empirical analysis of textile weaving. Accounting Review, 70, 363-388.

Arnold, D. (1994, February). Profits and prices: A lodging analysis. The Cornell Quarterly, pp. 3033.

Arthur Andersen \& Co. SC. (1993). The hotel operating statistics (HOST) report.

Arthur Andersen \& Co. SC. (1994). The hotel operating statistics (HOST) report. Bagozzi, R. P. (1986). Principles of marketing management. Chicago: Science Research Associates.

Banker, R. D., \& Johnston, H. H. (1993, July). An empirical study of cost drivers in the U.S.airline industry. Accounting Review, pp. 576-601.

Banker, R. D., Ou, C., \& Potter, G. (1997). The compensating impact of strategic cost drivers: Evidence from the U.S. banking industry. Working paper, Cornell University, Ithaca, New York.

Banker, R. D., Potter, G., \& Schroeder, R. G. (1995, February). An empirical analysis of manufacturing overhead cost drivers. Journal of Accounting and Economics, pp. 115138.

Chamberlin, E. (1962). The theory of monopolistic competition (8th ed.). Cambridge, MA: Harvard University Press. 
Cooper, R., \& Kaplan, R. S. (1987). How cost accounting systematically distorts product costs. In W. Bruns \& R. S. Kaplan (Eds.), Accounting and management: Field study experiments. Boston: Harvard Business School Press.

Cooper, R., \& Kaplan, R. S. (1991). The design of cost management system: Text, cases, and readings. Englewood Cliffs, NJ: Prentice Hall.

Cravens, D. W., \& Woodruff, R. B. (1986). Marketing. Reading, MA: Addison-Wesley.

DeFranco, A. (1997). The importance and use of financial forecasting and budgeting at the departmental level in the hotel industry as perceived by controllers. Hospitality Research Journal, 20(3), 99-110.

Foster, G., \& Gupta, M. (1990, January). Manufacturing overhead cost driver analysis. Journal of Accounting and Economics, pp. 309-337.

Gale, B. T., \& Branch, B. S. (1982). Concentration versus market share: Which determines market share and why does it matter? Antitrust Bulletin, 27, 83-105.

Hanks, R., Cross, R., \& Noland, R. (1992, February). Discounting in the hotel industry: A new approach. The Cornell Quarterly, pp. 15-23.

Hotel Association of New York City, Inc. (1986). A uniform system of accounts for hotels (8th ed.). New York: Author.

Hotels embrace value, abandon price pitch. (1993, September 6). Advertising Age.

Ittner, C., Larcker, D., \& Randall, T. (1996). The activity-based hierarchy and firm profitability. Working paper, University of Pennsylvania, Philadelphia.

Johnson, H. T., \& Kaplan, R. S. (1987). Relevance lost: The rise and fall of management accounting. Cambridge, MA: Harvard Business Press.

Kaplan, R. S. (1983, October). Measuring manufacturing performance: A new challenge for managerial accounting research. Accounting Review, pp. 686-705.

Kaplan, R. S. (1984, July). The evolution of management accounting. Accounting Review, pp. 390-418.

Lancaster, K. (1990, Summer). The economics of product variety. Marketing Science, pp. 189206.

MacDuffie, J. P., Sethuranman, K., \& Fisher, M. L. (1996, March). Product variety and manufacturing performance: Evidence from the international automotive assembly plant study. Management Science, pp. 350-369.

Miller, J. G., \& Vollmann, T. E. (1985, September/October). The hidden factory. Harvard Business Review. 
Noreen, E., \& Soderstrom, N. (1994, January). Are overhead costs strictly proportional to activity? Evidence from hospital services departments. Journal of Accounting and Economics, pp. 255-278.

Panzar, J. C., \& Willig, R. D. (1977). Economies of scale and economies of scope in multioutput production. Quarterly Journal of Economics, pp. 481-493.

PKF Consulting (1994). Trends in the hotel industry. San Francisco.

Porter, M. (1985). Competitive advantage. New York: Free Press.

Ravenscraft, D. J. (1983). Structure profit relationships at the line-of-business and level Industry. Review of Economics and Statistics, 65, 22-31.

Robinson, W. T., \& Fomell, C. (1985). Sources of market pioneer advantages in consumer goods industries. Journal of Marketing Research, 22, 305-317.

Scherer, F. M., \& Ross, D. (1990). Industrial market stucture and economic performance. Houghton Mifflin.

Schmidgall, R., \& Ninemeier, J. (1987, May). Budgeting in hotel chains: Coordination and control. The Cornell Quarterly, pp. 79-84.

Skinner, W. (1974, May/June). The focused factory. Harvard Business Review, pp. 113121.

Smith Travel Research. (1995). The HOST Study: 1994 hotel operating statistics. Hendersonville, TN: Author.

Stigler, G.J. (1983). The organization of industry. Chicago: University of Chicago Press. Why hotel rates won't take off. (1993, October 4). Fortune, p. 124.

Willig, R. D. (1979). Multi-product technology and market structure. American Economy Review, 69(2), 346-351. 